\%

THE HEAVENS ON EARTH

栄 
SCIENCE AND

CULTURAL THEORY

A Series Edited by

Barbara Herrnstein Smith

and E. Roy Weintraub 


\section{THE HEAVENS ON EARTH}

米

Observatories and

Astronomy in Nineteenth-

Century Science and Culture

Edited by DAVID AUBIN,

CHARLOTTE BIGG, and

H. OTTO SIBUM

DUKE UNIVERSITY PRESS

Durham and London

2010 
(C) 20ro Duke University Press

All rights reserved.

Printed in the United States

of America on acid-free paper @

Designed by Amy Ruth Buchanan

Typeset in Janson by Tseng

Information Systems, Inc.

Library of Congress Catalogingin-Publication Data appear on the last printed page of this book. 